\title{
TOXICODYNAMIC ASPECTS AND NEW TOOLS FOR ASSESSING ACETAMINOPHEN TOXICITY: A REVIEW
}

\section{REVIEW ARTICLE}

FRANCO, Fernando Wendel ${ }^{1}$, MALONN, Maíra Casali

FRANCO, Fernando Wendel. MALONN, Maíra Casali. Toxicodynamic aspects and new tools for assessing acetaminophen toxicity: a review. Revista Científica Multidisciplinar Núcleo do Conhecimento. Year 06, Ed. 12, Vol. 09, pp. 28-38. December 2021. ISSN:2448-0959, Access link in: https://www.nucleodoconhecimento.com.br/health/assessing-acetaminophen, DOI: 10.32749/nucleodoconhecimento.com.br/health/assessing-acetaminophen

\section{ABSTRACT}

Acetaminophen (Tylenol $\left.{ }^{\circledR}\right)$ or APAP is a widely used non-steroidal anti-inflammatory drug responsible for many cases of intoxication, suicide, and liver toxicity. Due to its toxicity mechanisms are not yet fully elucidated and this literature review aims to objectively bring some of the most recent and relevant scientific discoveries that can help in the understanding of the subject. After being ingested, paracetamol is absorbed and begins to be digested in the stomach, then being metabolized by the liver through phase I and phase II (glucuronyltransferases and sulfotransferases). When present in excess in the body, APAP forms an active metabolite known as $\mathrm{N}$ acetyl-para-benzoquinone-imine (NAPQI). This metabolite is a reactive species capable of binding to living cells and proteins causing damages, which are largely responsible for injuries, especially in the liver. As a conclusion of this study, it can be inferred that the lesions caused by acetaminophen, in addition to protein adducts, also extend to mitochondria and proteins. New markers, in addition to enzymes already known from the CYP families, also include proteins and cytokines, in addition

\footnotetext{
${ }^{1}$ Doctor in Pharmacology. Master in Toxicological Biochemistry. Postgraduate in Clinical Analysis. Graduated in Pharmacy. ORCID: 0000-0002-4762-5855.

${ }^{2}$ Master in Analytical Chemistry. Graduation in Chemistry Degree. ORCID: 0000-0002-2600-5964.
}

RC: 103832

Available in: https://www.nucleodoconhecimento.com.br/health/assessingacetaminophen 
to molecular methods, messenger RNA and micro RNA have been used to study hepatotoxicity by APAP. This makes it easier to deeply understand the mechanisms of toxicity induced by acetaminophen and then to advance in studies with new therapies.

Keywords: paracetamol, NAPQI, hepatotoxicity, mitochondrial damage.

\section{INTRODUCTION}

Acetaminophen $\left(\right.$ Tylenol $\left.{ }^{\circledR}\right)$ or APAP is a popular analgesic and antipyretic drug used all over the world. Adults and children in the United States use about 300 million bottles or packets of APAP or APAP-containing medications in various formulations as over the counter or prescription medicines each year. The highest suggested dose for adults and adolescents (13 years old) is $1,000 \mathrm{mg}$ after a single administration and 4,000 mg daily, according to the US Food and Drug Administration. To account for variations in metabolism between adults and children, dosage reduction is advised in children (2-12 years) based on the patient's age or body weight. (JI et al., 2012; JIANG et al., 2013).

Despite not having the same anti-inflammatory action as other medicines in the class, APAP is categorized as a nonsteroidal anti-inflammatory drug (NSAID). It's been described as a medication linked to hazardous ingestions during suicide attempts or when it's not utilized properly. Like other NSAIDs, it is also known for not producing significant gastrointestinal adverse effects. In the Western world, acetaminophen (APAP) overdose is a leading cause of abrupt liver failure and damage (LARSON et al., 2005).

Hepatic metabolism of APAP is recognized to be a key role in hepatotoxicity development. APAP is largely metabolized by conjugation events after low dosage exposure, with oxidation processes playing a minor role. However, when large dosages of APAP are administered, conjugation routes become saturated, and a

RC: 103832

Available in: https://www.nucleodoconhecimento.com.br/health/assessingacetaminophen 
greater proportion of the medication undergoes oxidative metabolism (WALUBO et al., 2004).

CYP450 enzymes (a superfamily of hemoproteins that catalyzes the oxidative metabolism of numerous exogenous drugs and endogenous substances) metabolize the hepatotoxic metabolites of APAP. APAP bioactivation increases hepatotoxicity in the human liver, and the CYP isoforms enzymes CYP2E1, CYP1A2, and CYP3A4 are largely responsible for this (MANYIKE et al., 2000).

The oxidation produces the reactive metabolite $\mathrm{N}$-acetyl-p-benzoquinone imine (NAPQI), which is regarded as a crucial starting step in the development of hepatotoxicity, coupled with the depletion of hepatic glutathione (DONG et al., 2020). NAPQI binds to cysteine groups on proteins, forming APAP protein adducts that are produced from centrilobular hepatocytes, along with large quantities of alanine aminotransferase (ALT) and aspartate aminotransferase (AST) that reach the peripheral blood after hepatocyte lysis (JARSIAH et al., 2017).

\section{APAPS' TOXICODYNAMIC}

\subsection{APAPS' TOXICITY MECHANISM}

APAP toxicity is characterized by four distinct stages, defined in time after ingestion. Stage I: occurs within the first 24 hours after ingestion. This is the most critical stage and is characterized by clinical findings such as nausea, malaise, vomiting, pallor, lethargy, anorexia, and sweating. Some patients remain asymptomatic during this stage.

Stage II: 24 to 72 hours after ingestion. Initially, signs and symptoms refer to the same as in the previous stage and patients appear to improve clinically while liver aminotransferases (AST, ALT) increase. As stage II progresses, patients develop pain in the upper right quadrant, with hepatomegaly and liver tenderness. Elevations

RC: 103832

Available in: https://www.nucleodoconhecimento.com.br/health/assessingacetaminophen 
in serum prothrombin time (PT) and levels of total bilirubin and abnormalities of renal function may develop (SACCOMANO et al., 2019).

Stage III: 72 to 96 hours after ingestion. During this phase, the signs and symptoms become more pronounced. Systemic findings, including malaise, nausea, and vomiting, return and may be accompanied by central nervous system involvement, such as confusion, drowsiness, and possible coma. Jaundice, as well as pancreatic, renal and cardiac damage, may be present. Abnormalities such as spikes in serum enzymes AST, ALT, bilirubin and proteins levels are frequently detected, with AST levels elevated to $1,000 \mathrm{U} / \mathrm{L}$ and can increase up to $30,000 \mathrm{U} / \mathrm{L}$ (normal, 10 to 40 $\mathrm{U} / \mathrm{L}$ ) in paracetamol toxicity serious. Serum PT levels greater than 2.2 times the control (normal, 11.0 to 13.0 seconds) and total bilirubin levels greater than $4 \mathrm{mg} / \mathrm{dL}$ (normal, 0.3 to $1.0 \mathrm{mg} / \mathrm{dL}$ ) indicate severe hepatotoxicity.

Stage IV: 4 days to 2 weeks post-ingestion (recovery phase). Stage IV represents the period of resolution of liver damage. During this phase, clinical signs, symptoms, and laboratory values return to near baseline values and permanent damage occurs infrequently; this demonstrates that the patient received specific treatment at some point during Stage II (SACCOMANO et al., 2019).

\subsection{LIVER DAMAGE}

Doses greater than $140 \mathrm{mg} / \mathrm{kg}$ or $7.5 \mathrm{~g}$ of APAP are considered toxic and can trigger severe or fatal central-lobular necrosis. Once the therapeutic dose is exceeded, the sulfation and glucuronidation pathways are saturated. This results in an increase in the production of NAPQI through the enzymes of the P450 system. This metabolite generates an increased consumption of reduced glutathione. (HEARD et al., 2014).

Oxidative stress is also related to hepatotoxicity. Through the increase in the formation of the NAPQI metabolite, a depletion in the cellular levels of reduced Glutathione occurs. This causes the enzyme glutathione peroxidase to have its activity also decreased, resulting in the accumulation of peroxides. Oxidative stress

RC: 103832

Available in: https://www.nucleodoconhecimento.com.br/health/assessingacetaminophen 
can also occur as a result of a pathway for the co-production of the superoxide radical and hydrogen peroxide, these resulting from the redox cycle between the APAP semiquinone radical and NAPQI (SHON et al., 2004).

Experiments on animal species susceptible to APAP were carried out to further discover new mechanisms of hepatotoxicity. Different degrees of hepatic necrosis were found when PAR was administered to animals pretreated with inducers of microsomal enzymes (CHIEW et al., 2020). On the other hand, it was also observed that the damage was reduced in animals that received inhibitors of these enzymes. Similarly, in humans exposed to enzyme-inducing drugs such as phenobarbital or ethanol, they are more susceptible to paracetamol hepatotoxicity. On the contrary, resistance to these effects has been described in patients undergoing the use of cimetidine, an inhibitor of the microsomal enzyme system p450 (FATHELRAHMAN et al., 2021).

\subsection{MITOCHONDRIAL DAMAGE}

After an overdose of APAP, the formation of NAPQI exceeds the detoxification capacity of glutathione, resulting in covalent binding to cellular proteins. Other injury mechanisms occur with mitochondrial changes and a consequent decrease in energy production.

Several proteins involved in ionic balance can be affected, impairing the physiological functioning of cells. The loss of this correct functioning by the mitochondria or by the nucleus leads to an increase in cytosolic and mitochondrial $\mathrm{Ca}^{2+}$. This increase, in turn, can induce the activation of proteases and endonucleases and, consequently, lesions in the DNA molecule. The result of this may be the loss of activity or function of many proteins, with eventual death or cell lysis (BRINI et al., 2003).

Although the protein binding of adducts caused by an overdose of APAP or its 30hydroxyacetanilide isomer is similar and in many protein adducts, toxicity occurred 
only with APAP, which shows a greater binding of this to mitochondrial proteins (KENNA et al., 2013; MCGILL et al., 2012).

Subsequent mitochondrial dysfunction leads to inhibition of mitochondrial respiration, depletion of ATP, a form of reactive oxygen, and peroxynitrite (ROS and RNS) within the mitochondria (HWANG et al., 2015; JAESCHKE et al., 2003). Oxidative stress is involved in the activation of the c-Jun-N-terminal (JNK) kinase pathway and eventually triggers the opening of the mitochondrial membrane (MPT) permeability transition pore, resulting in the collapse of the mitochondrial membrane potential (SAITO et al., 2010).

Swelling of the mitochondrial matrix and rupture of the outer membrane causes the release of intermembrane proteins, including cytochrome $c$, endonuclease $G$, and apoptosis-inducing factor (AIF). Only endonuclease $G$ and AIF translocate to the nucleus and induce DNA fragmentation (RAMACHANDRAN et al., 2011).

Severe impairment of aerobic energy metabolism, massive ATP depletion, and damage to nuclear DNA result in necrotic cell death (FERNÁNDEZ-CHECA et al., 2003). After the release of cytochrome $c$ from the mitochondria, caspases are released contributing to apoptosis in mice (KON et al., 2004). The formation of the protein adduct occurs in parallel with the consumption of GSH and does not require extensive depletion of GSH. These adducts were detected in HepaRG cells and HepG2 cells before significant effects on GSH levels and well before any evidence of mitochondrial dysfunction and cell death (VAN DEN EEDE et al., 2015).

\subsection{TOXICITY ASSESSMENT TOOLS}

Recently, new markers have been developed to assess hepatotoxicity caused by APAP. For example, cytochemical studies using anti-paracetamol antibodies have shown that covalent binding of paracetamol metabolites occurs in the damaged centrilobular regions of the human liver after an overdose (COUGHTRIE et al., 1990).

RC: 103832

Available in: https://www.nucleodoconhecimento.com.br/health/assessingacetaminophen 
Other studies show that human serum microRNA-122 (miR-122) can be used as a new biomarker of APAP-induced liver damage (YANG et al., 2015). Furthermore, acetaminophen-cysteine adducts (APAP-CYS) are a specific biomarker of acetaminophen exposure. The presence of APAP-CYS has been described as clinical findings in cases of acute overdose, and a concentration $>1.1 \mathrm{nmol} / \mathrm{ml}$ has been suggested as a marker for the establishment of liver damage caused by an overdose of paracetamol in patients with ALT> 1000 IU / L (GALVIN et al., 2015).

APAP protein adducts are released into the blood during the lysis of hepatocytes and the concentration of adducts in the serum of patients with overdose is correlated with toxicity. Detection of APAP - protein adducts using high-pressure liquid chromatography with electrochemical detection reliably identified APAP hepatotoxicity and, therefore, can be a useful diagnostic test for patients who overdose after a few days (KHANDELWAL et al., 2011; WILLIAMS et al., 2014).

Other metabolomic tools have allowed the study of new mechanisms of liver injury in experimental models of drug toxicity. The interruption of bile acid homeostasis is a known mechanism of drug-induced liver injury (GARCÍA-CAÑAVERAS et al., 2016). Some candidates proposed for early biomarkers of paracetamol hepatotoxicity include proteins, cytokines, messenger RNAs, and microRNAs (miRNAs) (AMACHER et al., 2013).

First described in 1993, miRNAs are short sequences of non-coding RNA that influence a wide range of physiological processes through effects on gene regulation and protein synthesis. To date, more than 2,000 human miRNAs have been identified, and that list is growing. MicroRNAs are known to be stable in circulation and, unlike protein biomarkers, they are not susceptible to post-translational modifications. MicroRNAs are usually intracellular and often tissue-specific. They are released with cellular stress, making the extracellular levels of miRNA an excellent marker of tissue damage. Serum and tissue profiles of these biomarkers are currently under investigation for the detection and treatment of multiple subtypes of cancer, neurological diseases, and cardiovascular diseases (ZHOU et al., 2018). 
MicroRNA profiles have enormous potential in the diagnosis and mechanistic exploration of paracetamol hepatotoxicity. Significant changes in circulating miRNA profiles from various biological matrices (eg, blood, urine) have been demonstrated in mouse and rat models of acetaminophen toxicity. In humans, major miRNAs were significantly upregulated in urine, hepatocytes, and blood. Human studies have largely focused on liver-associated miRNAs, specifically miR-122, which has been repeatedly considered elevated in paracetamol hepatotoxicity. More recent studies have focused on expanded miRNA panels as markers, facilitators, and inhibitors of paracetamol-induced hepatotoxicity (DEAR et al., 2018).

There is a correlation with the elevation of CYP regulatory miRNA levels correlated with elevations of APAP protein adducts in cells of patients with APAP-induced toxicity. Initial studies of miRNA expression in APAP toxicity reported elevations in the specific miR-122-5p in the liver and its correlation with elevation in ALT; miR-122 may also represent a predictive biomarker of APAP-induced liver injury. Yamaura et al. used a mouse model of APAP toxicity and described the elevation of miR-122, as well as miR-192, miR-685, miR-193, and miR-29c12. High-performance omic analysis using human APAP overdose samples suggested that miR-122-5p15-18, miR-27b-3p15,16, and miR-125b-5p15,17 were sensitive and non-invasive biomarkers for APAP toxicity. In the study in question, a strong association was observed between miR-122-5p, miR-378a-5p, miR-125b-5p, and miR-27b-3p in liver damage caused by APAP (GILL et al., 2017).

These elevations may represent cell-to-cell communication in an attempt to minimize toxic events in cells or to stimulate hepatocyte repair responses. A better understanding of the role of miRNAs in APAP-induced hepatotoxicity may be relevant to the development of new treatments for APAP toxicity and/or an understanding of individual susceptibility to drug toxicity. The results provide new insights into the protective role of miR-122 and miR-378a in suppressing the expression of drugmetabolizing enzymes. 


\section{CONCLUSION}

Although paracetamol is a drug widely used worldwide, all its mechanisms of action and excretion are still not well known to the general population. Its wide use makes the risk of toxic ingestion very great. The new markers may assist in the detection of liver damage caused by APAP. Knowledge of these mechanisms of action can influence the search for new drugs and drug therapies against hepatotoxicity caused by APAP.

This work intends to gather some of the most recent scientific data about the biochemical and molecular markers of APAP to elucidate and make the population aware of its rational and conscious use.

\section{REFERENCES}

AMACHER, DAVID E., SCHOMAKER, SHELLI J., AUBRECHT, JIRI. Development of blood biomarkers for drug-induced liver injury: an evaluation of their potential for risk assessment and diagnostics. Molecular diagnosis \& therapy, v. 17, n. 6, p. 343-354, 2013. Disponível em: https://link.springer.com/article/10.1007\%2Fs40291013-0049-0. Acesso em 17/05/2020.

CHIEW, A. L., DOMINGO, G., BUCKLEY, N. A., STATHAKIS, P., RESS, K., ROBERTS, D. M. (2020). Hepatotoxicity in a child following an accidental overdose of liquid paracetamol. Clinical toxicology, 58(11), 1063-1066. Disponível em: https://pubmed.ncbi.nlm.nih.gov/32067495/. Acesso em 14/05/2020.

COUGHTRIE, M., SHARP, S. Purification and immunochemical characterization of a rat liver sulphotransferase conjugating paracetamol. Biochemical pharmacology, $v$. 40, n. 10, p. 2305-2313, 1990. Disponível em: (sítio). Acesso em 04/05/2020.

DEAR, J. W., CLARKE, J. I., FRANCIS, B., ALLEN, L., WRAIGHT, J., SHEN, J., ANTOINE, D. J. (2018). Risk stratification after paracetamol overdose using mechanistic biomarkers: results from two prospective cohort studies. The Lancet

RC: 103832

Available in: https://www.nucleodoconhecimento.com.br/health/assessingacetaminophen 
Gastroenterology \& Hepatology, 3(2), 104-113. Disponível em: https://pubmed.ncbi.nlm.nih.gov/2244932/. Acesso em 12/04/2020.

DONG, H., haINING, R. L., THUMMEL, K. E., RetTIE, A. E., NELSON, S. D. (2000). Involvement of human cytochrome P450 2D6 in the bioactivation of acetaminophen. Drug metabolism and disposition, 28(12), 1397-1400. Disponível em: https://pubmed.ncbi.nlm.nih.gov/11095574/. Acesso em 14/01/2020.

FATHELRAHMAN, A. I. Ten Challenges Associated with Management of Paracetamol Overdose: An Update on Current Practice and Relevant Evidence from Epidemiological and Clinical Studies. Journal of Clinical \& Diagnostic Research, v. 15, n. 3, 2021. Disponível em: https://www.jcdr.net/article_fulltext.asp?issn=0973709x\&year=2021\&volume=15\&issue=3\&page $=F E 01 \& i s s n=0973-709 x \& i d=14580$. Acesso em 10/05/2020.

FERNÁNDEZ-CHECA, J. C. Redox regulation and signaling lipids in mitochondrial apoptosis. Biochemical and biophysical research communications, v. 304, n. 3, p. 471-479, 2003. Disponível em: https://pubmed.ncbi.nlm.nih.gov/12729581/. Acesso em 11/05/2020.

GALVIN, Z., MCDONOUGH, A., RYAN, J., STEWART, S. (2015). Blood alanine aminotransferase levels> 1,000 IU/l-causes and outcomes. Clinical medicine, 15(3), 244. Disponível em: https://www.ncbi.nlm.nih.gov/pmc/articles/PMC4953107/. Acesso em 03/05/2020.

GARCíA-CAÑAVERAS, J. C., CASTELL, J. V., DONATO, M. T., LAHOZ, A. (2016). A metabolomics cell-based approach for anticipating and investigating drug-induced liver injury. Scientific reports, 6(1), 1-12. Disponível em: https://www.nature.com/articles/srep27239. Acesso em 14/02/2020.

GILL, P., BHATTACHARYYA, S., MCCULLOUGH, S., LETZIG, L., MISHRA, P. J., LUO, C., JAMES, L. (2017). MicroRNA regulation of CYP 1A2, CYP3A4 and CYP2E1 
expression in acetaminophen toxicity. Scientific reports, 7(1), 1-11. Disponível em: https://www.nature.com/articles/s41598-017-11811-y. Acesso em 20/05/2020.

HEARD, K., RUMACK, B. H., GREEN, J. L., BUCHER-BARTELSON, B., HEARD, S., BRONSTEIN, A. C., DART, R. C. (2014). A single-arm clinical trial of a 48-hour intravenous $\mathrm{N}$-acetylcysteine protocol for treatment of acetaminophen poisoning. Clinical Toxicology, 52(5), 512-518. Disponível em: https://pubmed.ncbi.nlm.nih.gov/24708414/. Acesso em 14/05/2020.

HWANG, J. H., KIM, Y. H., NOH, J. R., GANG, G. T., KIM, K. S., CHUNG, H. K., LEE, C. H. (2015). The protective role of NAD (P) H: quinone oxidoreductase 1 on acetaminophen-induced liver injury is associated with prevention of adenosine triphosphate depletion and improvement of mitochondrial dysfunction. Archives of toxicology, $\quad 89(11), \quad 2159-2166 . \quad$ Disponível em: https://pubmed.ncbi.nlm.nih.gov/25224400/. Acesso em 04/03/2020.

JAESCHKE, H., KNIGHT, T. R.; BAJT, M. L. The role of oxidant stress and reactive nitrogen species in acetaminophen hepatotoxicity. Toxicology Letters, v. 144, n. 3, p. 279-288, 2003. Disponível em: https://pubmed.ncbi.nlm.nih.gov/12927346/. Acesso em 09/05/2020.

JI, P., WANG, Y., LI, Z., DODdAPANENI, S., HERTZ, S., FURNESS, S., SAHAJWALLA, C. G. (2012). Regulatory review of acetaminophen clinical pharmacology in young pediatric patients. Journal of pharmaceutical sciences, 101(12), 4383-4389. Disponível em: https://pubmed.ncbi.nlm.nih.gov/23073837/. Acesso em 11/05/2020.

JIANG, X. L., ZHAO, P., BARRETT, J. S., LESKO, L. J., SCHMIDT, S. (2013). Application of physiologically based pharmacokinetic modeling to predict acetaminophen metabolism and pharmacokinetics in children. CPT: pharmacometrics \& systems pharmacology, 2(10), 1-9. Disponível em: (sítio). Acesso em 01/05/2020. 
KHANDELWAL, N., JAMES, L. P., SANDERS, C., LARSON, A. M., LEE, W. M. Acute Liver Failure Study Group. (2011). Unrecognized acetaminophen toxicity as a cause of indeterminate acute liver failure. Hepatology, 53(2), 567-576. Disponível em: https://www.ncbi.nlm.nih.gov/pmc/articles/PMC3208905/. Acesso em 14/05/2020.

KENNA, J. G. A new twist to an old tale: novel insights into the differential toxicities of acetaminophen and its regioisomer $\mathrm{N}$-acetyl-meta-aminophenol (AMAP). Archives of toxicology, v. $87, \quad$ n. $1, \quad$ p. 15-18, 2013. Disponível em: https://link.springer.com/article/10.1007/s00204-012-0945-9. Acesso em 14/06/2020.

KON, K., KIM, J. S., JAESCHKE, H., LEMASTERS, J. J. (2004). Mitochondrial permeability transition in acetaminophen-induced necrosis and apoptosis of cultured mouse hepatocytes. Hepatology, 40(5), 1170-1179. Disponível em: https://pubmed.ncbi.nlm.nih.gov/15486922/. Acesso em 14/07/2020.

LARSON, A. M., POLSON, J., FONTANA, R. J., DAVERN, T. J., LALANI, E., HYNAN, L. S. (2005). Acetaminophen-induced acute liver failure: results of a United States multicenter, prospective study. Hepatology, 42(6), 1364-1372. Disponível em: https://pubmed.ncbi.nlm.nih.gov/16317692/. Acesso em 14/05/2020.

MANYIKE, P. T., KHARASCH, E. D., KALHORN, T. F., SLATTERY, J. T. (2000). Contribution of CYP2E1 and CYP3A to acetaminophen reactive metabolite formation. Clinical Pharmacology \& Therapeutics, 67(3), 275-282. Disponível em: https://pubmed.ncbi.nlm.nih.gov/10741631/. Acesso em 14/05/2020.

MCGILL, M. R., WILLIAMS, C. D., XIE, Y., RAMACHANDRAN, A., JAESCHKE, H. (2012). Acetaminophen-induced liver injury in rats and mice: comparison of protein adducts, mitochondrial dysfunction, and oxidative stress in the mechanism of toxicity. Toxicology and applied pharmacology, 264(3), 387-394. Disponível em: https://pubmed.ncbi.nlm.nih.gov/22980195/. Acesso em 04/05/2020. 
RAMACHANDRAN, A., LEBOFSKY, M., WEINMAN, S. A., JAESCHKE, H. (2011). The impact of partial manganese superoxide dismutase (SOD2)-deficiency on mitochondrial oxidant stress, DNA fragmentation and liver injury during acetaminophen hepatotoxicity. Toxicology and applied pharmacology, 251(3), 226-233. Disponível em: https://pubmed.ncbi.nlm.nih.gov/21241727/. Acesso em 14/08/2020.

SACCOMANO, S. J. Acute acetaminophen toxicity in adults. Nursing2020 Critical Care, v. $14, \quad$ n. $5, \quad$ p. 10-17, 2019. Disponível em: https://pubmed.ncbi.nlm.nih.gov/31651762/. Acesso em 04/08/2020.

SAITO, C., LEMASTERS, J. J., JAESCHKE, H. C-Jun N-terminal kinase modulates oxidant stress and peroxynitrite formation independent of inducible nitric oxide synthase in acetaminophen hepatotoxicity. Toxicology and applied pharmacology, v. 246, n. 1-2, p. 8-17, 2010. Disponível em: https://pubmed.ncbi.nlm.nih.gov/20423716/. Acesso em 19/08/2020.

SHON, Y., NAM, K. Protective effect of Moutan Cortex extracts on acetaminopheninduced hepatotoxicity in mice. Journal of ethnopharmacology, v. 90, n. 2-3, p. 415-419, 2004. Disponível em: https://pubmed.ncbi.nlm.nih.gov/15013210/. Acesso em $11 / 08 / 2020$.

VAN DEN EEDE, N., CUYKX, M., RODRIGUES, R. M., LAUKENS, K., NEELS, H., COVACI, A., VANHAECKE, T. (2015). Metabolomics analysis of the toxicity pathways of triphenyl phosphate in HepaRG cells and comparison to oxidative stress mechanisms caused by acetaminophen. Toxicology in Vitro, 29(8), 2045-2054. Disponível em: https://pubmed.ncbi.nlm.nih.gov/26318275/. Acesso em 14/01/2020.

WAlubo, A., BARR, S., ABraham, A. M., COETSEe, C. (2004). The role of cytochrome-P450 inhibitors in the prevention of hepatotoxicity after paracetamol overdose in rats. Human \& experimental toxicology, 23(1), 49-54. Disponível em: https://pubmed.ncbi.nlm.nih.gov/15027815/. Acesso em 04/02/2020. 
WILLIAMS, C. D., MCGILL, M. R., LEBOFSKY, M., BAJT, M. L., JAESCHKE, H. (2014). Protection against acetaminophen-induced liver injury by allopurinol is dependent on aldehyde oxidase-mediated liver preconditioning. Toxicology and applied pharmacology, 274(3), 417-424. Disponível em: https://www.ncbi.nlm.nih.gov/pmc/articles/PMC3939778/. Acesso em 14/08/2020.

YANG, X., SALMINEN, W. F., SHI, Q., GREENHAW, J., GILL, P. S., BHATTACHARYYA, S., JAMES, L. P. (2015). Potential of extracellular microRNAs as biomarkers of acetaminophen toxicity in children. Toxicology and applied pharmacology, 284(2), 180-187. Disponível em: https://pubmed.ncbi.nlm.nih.gov/25708609/. Acesso em 14/08/2020.

ZHOU, S. S., JIN, J. P., WANG, J. Q., ZHANG, Z. G., FREEDMAN, J. H., ZHENG, Y., CAI, L. (2018). miRNAS in cardiovascular diseases: potential biomarkers, therapeutic targets and challenges. Acta Pharmacologica Sinica, 39(7), 1073-1084. Disponível em: https://pubmed.ncbi.nlm.nih.gov/29877320/. Acesso em 12/08/2020.

Posted: April, 2021.

Approved: December, 2021. 